\title{
SEASONAL GROWTH OF SOME TREES IN ONTARIO ${ }^{1}$
}

\author{
By R. M. BELYEA2, D. A. FRASER ${ }^{2}$ and A. H. ROSE 3
}

\section{INTRODUCTION}

Most of the recent work on the course of seasonal growth in forest trees has been carried out in Europe and in the United States, and information for Canada is very inadequate. Some records for British Columbia have been published by Warrack and Jorgensen (13), but so far as is known, no records have been published on seasonal growth in Ontario. Studies of seasonal growth of forest trees in Ontario have been in progress during the past five years as part of the investigative program of the Forest Insect Laboratory, Sault Ste. Marie. This paper describes the method and the general course of seasonal development in some of the more important tree species of the region.

\section{METHODS AND Materials}

Various methods have been employed in the study of radial increment in forest trees. Jost (6) and Hartig (5) studied periodic growth by selecting even-aged stands where samples could be obtained from trees felled at different times during the growth period. Results obtained by this method were complicated by inter-tree variability. Von Mohl (12) and Friedrich (3) made measurements of the circumference of the tree bole. MacDougal (9) and others used a dendrograph consisting of a band of invar links surrounding the trunk. This apparatus is expensive and a separate instrument is required for each tree under observation.

In recent years, instruments known as "dendrometers" have been developed which allow the course of radial increment throughout the year to be followed in many trees with a single instrument. All of these operate on the principle of measuring the change in distance, as the tree grows in diameter, between a plate fastened to the bark and a reference plane anchored in the wood.

Several dendrometers have been described in the literature. Reineke (10), Daubenmire (2), Tryon and Finn (11), Warrack and Jorgensen (13), and Bryam and Doolittle (1) developed instruments employing dial gauges with various means of application to the tree. During current studies at the Forest Insect Laboratory, a dendrometer (Figs. 1 and 2) has been developed which is believed to have advantages over those already described. The instrument illustrated is the third model developed, and embodies improvements over the earlier models.

A standard dial gauge ${ }^{4}$ graduated in thousands of inches with a spindle travel of one inch is used as the measuring device. It is mounted with the

1. Contribution No. 15, Division of Forest Biology, Science Service, Department of Agri-

2. Associate Entomologist, - 3. Assistant Entomologist, Forest Insect Laboratory, Sault

4. No. 282, manufactured by the B. C. Ames Co. of Waltham Mass., U.S.A., available in Canada from H. C. Burton Co. Litd., Hamilton, Ontario. 
spindle projecting through a triangular base of one-quarter-inch "Dural" plate, to which it is attached by a brass block. Three pointed legs, one inch in length, made from sharpened stove bolts, are attached to the base plate by lock washers and nuts. A small metal collar and rubber gasket are inserted between the gauge and the base plate to leave a slight clearance for such movement of the dial face as may occasionally be necessary for adjustment.

The reference plane in each tree is established by three 1.5 -inch flatheaded wood screws. They are set into the tree in such a way that each leg of the instrument can rest in the slot of a screw(Fig. 2). Since the legs of

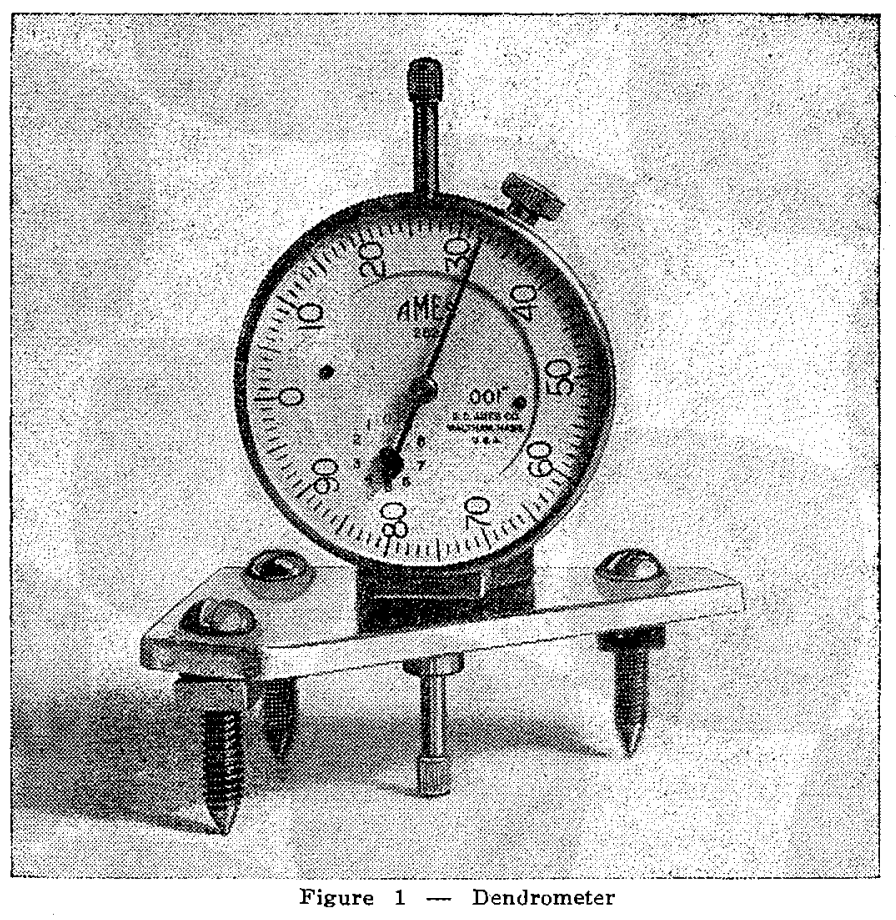

the dendrometer are placed to form a right-angled scalene triangle, and the screw lots are adjusted so that two are in line and the third perpendicular to that line, the instrument can rest on the screws in only one position. This ensures a constant reference plane for successive readings. A flat-headed brass thumbtack, with the shank shortened, is glued to the bark to form the bearing point for the gauge spindle. The arrangement of the screws in the tree ensures a distance of one inch between the perpendicular lines through the screws and the bark reference (Fig. 2), thus eliminating possible interference with growth by the wood screws at the point of measurement.

Some distinct advantages of this instrument have become evident. In some of the other dendrometers, the screws forming the reference plane must 
be precisely located in the tree, which is often difficult, especially in trees of small diameter. This is not necessary with the three-legged instrument and slotted wood screws, where the point of each leg rests in a screw slot approximately three-eighths of an inch in length, which allows considerable leeway in the placing of the screws. In addition, the instrument is constructed of easily obtained materials, and no skilled machining is necessary.

Increment records have been obtained in the vicinity of the following points in Ontario:

Chalk River, Lat. $45^{\circ} 58^{\prime} \mathrm{N}$, Long. $77^{\circ} 31^{\prime} \mathrm{W}$, approximately 100 miles northwest of Ottawa. The area is in the Algonquin-Laurentides section of the Great Lakes-St. Lawrence Forest Region (4).

Black Sturgeon Lake, Lat. $49^{\circ} 22^{\prime} \mathrm{N}$, Long. $88^{\circ} 50^{\prime} \mathrm{W}$, approximately 65 miles northeast of Port Arthur. The area is in the Superior section of the Boreal Forest Region.

Cedar Lake, $50^{\circ} 15^{\prime} \mathrm{N}$, Long. $93^{\circ} 15^{\prime} \mathrm{W}$, approximately 60 miles northeast of Kenora. The area is in the eastern portion of the English River section of the Boreal Forest Region.

Seasonal radial increment was studied in the following tree species:

Chalk RIVER

White spruce (Picea glauca (Moench) Voss)

White birch (Betula papyrifera Marsh.)

White pine (Pinus Strobus L.)

Hemlock (Tsuga canadensis (L) Carr.)

Black ash (Fraxinus nigra Marsh.) Sugar maple (Acer saccharum Marsh.) Basswood (Tilia americana L.) Beech (Fagus grandifolia Ehrh.) Yellow birch (Betula lutea Michx. f.)
CEDAR LAKE

White spruce (Picea glauca (Moench) Voss)

White birch (Betula papyrifera Marsh.)

Black spruce (Picea mariana (Mill.) B.S.P.)

Tamarack (Larix laricina (Du Roi) K. Koch)

Jack pine (Pinus Banksiana Lamb.)

Balsam fir (Abies balsamea (L.) Mill.)

Trembling aspen (Populus tremuloides Michx.)

Black Sturgeon LAKE

Balsam fir (Abies balsamea (L.) Mill.)

The growth records for balsam fir at Black Sturgeon Lake are of particular interest in connection with deterioration following spruce budworm attack, and are not discussed in this communication.

Average cumulative radial increment curves for certain of these species in 1950 are shown graphically in Fig. 3. These records represent the total of swelling and deposition of new xylem, phloem and periderm. In general, three phases are represented in the curves: (a) initial swelling which lasts at least a week, and marks the upward passage of water, (b) active cell division indicating the grand period of growth, and (c) cessation of increment accompanied by dehydration of the cells and preparation of the cam- 
bium for its winter rest. In the following discussion, the terms radial increment and decrement refer to all changes in the radial dimension of the tree, whereas the term radial growth refers only to those changes caused by cell division.

\section{Development in Two Localities}

White spruce and white birch were studied in both the Chalk River and Cedar Lake areas. In white spruce, there was a difference of 18 days (May 11, Chalk R; May 29, Cedar Lake) in time of initiation of radial growth at the two places. The difference in the time by which 50 per cent of radial growth had taken place was even greater (June 13, Chalk River; July 10 , Cedar Lake). Growth terminated August 19 at Chalk River, two weeks earlier than at Cedar Lake. The duration of growth was almost the same,

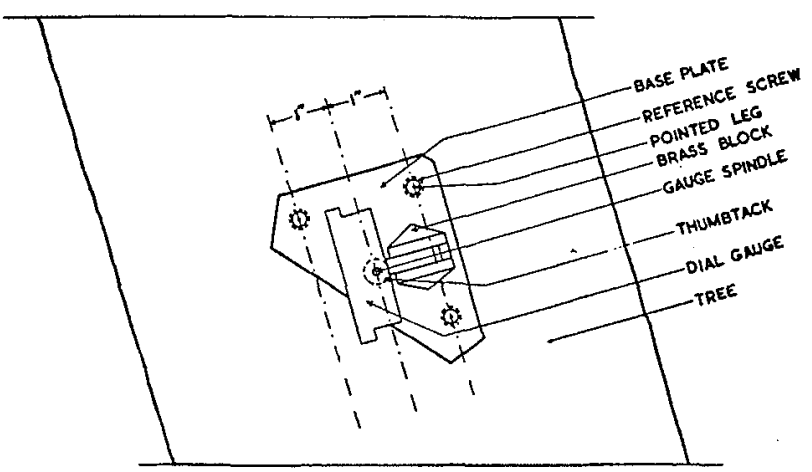

Figure 2-Diagrammatic representation of dendrometer in position on tree reference screws.

about 100 days in the two areas. Mean temperature based on readings every two hours from May 22 to the end of August was $62.6^{\circ} \mathrm{F}$. at Chalk River and $58.4^{\circ} \mathrm{F}$. at Cedar Lake. Weekly mean temperature at Chalk River exceeded those at Cedar Lake by about $7^{\circ} \mathrm{F}$. up to mid-July; however, from mid-July to the end of August, mean temperatures were almost identical at the two locations.

Although initiation and cessation of radial growth in white birch occurred 10 days earlier at Chalk River, the time by which 50 per cent of growth had taken place was almost identical at both places.

\section{Development in Different SPecies}

At Chalk River, radial growth commenced first in white spruce and hemlock on May 11, then in black ash four days later, and finally in basswood, yellow birch, white birch, sugar maple, beech and white pine. Practically the same order was maintained in the time by which 50 per cent of seasonal radial growth had taken place, although the spread be- 
tween the earliest and latest species was about one month. Cessation of radial growth for all trees with the exception of white spruce occurred almost simultaneouly about August 28.

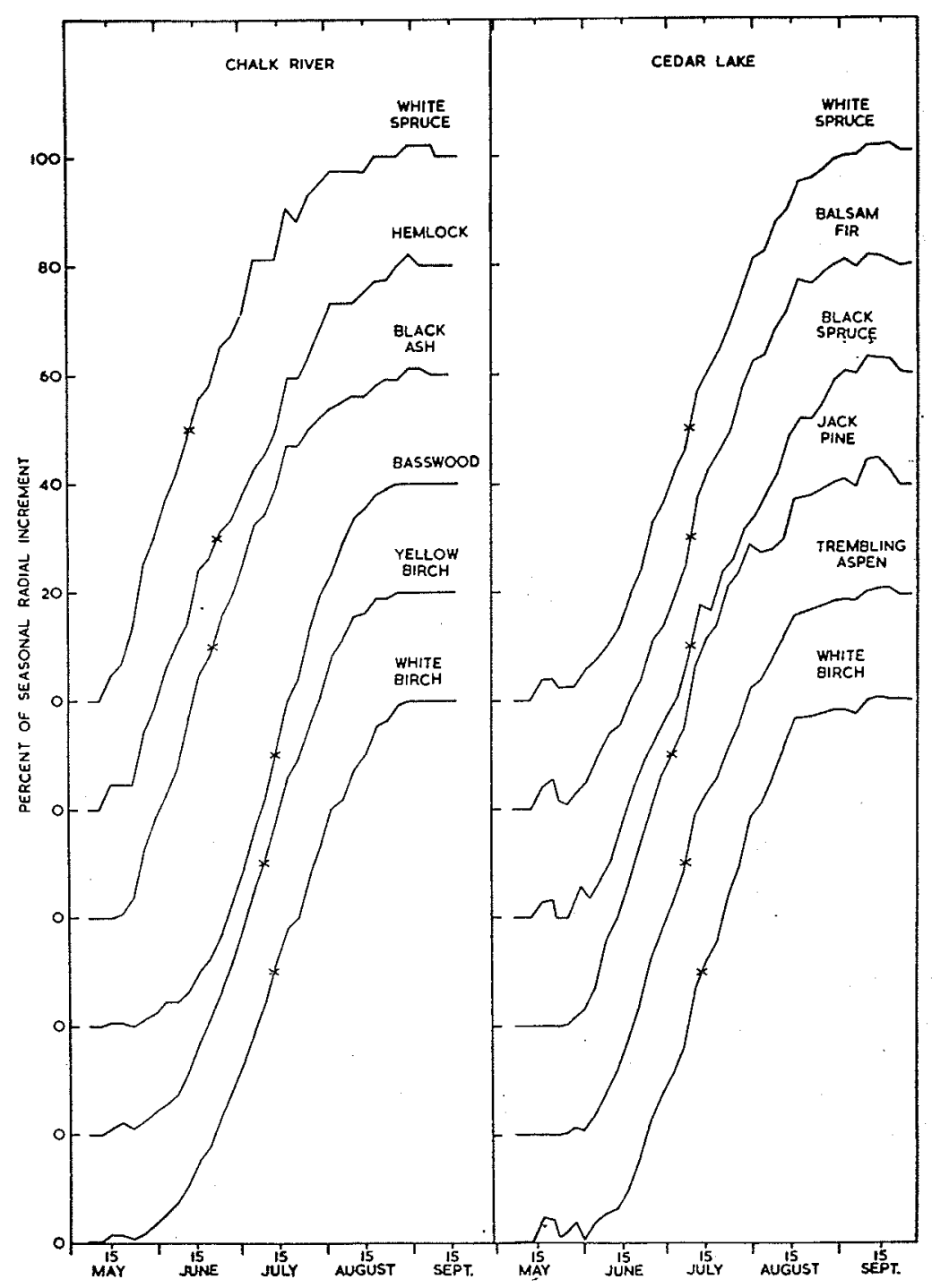

Figure 3-Average seasonal radial increment curves for tree specles, 1950. The date by which 60 percent of total seasonal increment was completed is indicated by " $X$ " on the individual curves. 
At Cedar Lake, radial growth commenced first in balsam fir and jack pine on May 26, then in white spruce three days later, and finally in trembling aspen, white birch and black spruce. Fifty per cent of seasonal radial growth in jack pine had been laid down by July 3 followed by trembling aspen, white spruce, balsam fir, black spruce and white birch within the next 10 days. Cessation of growth occurred first in jack pine and balsam fir on August 30, then in white spruce and black spruce four days later, and finally in white birch and trembling aspen on September 11.

Detailed information on the growing periods and the characteristic growth curves of tree species has been of considerable help in analysis of the effect of insects and other factors on tree growth and deterioration. More detailed records of seasonal radial and shoot growth of forest trees will be published later in separate contributions on forest insect problems in Ontario.

\section{REFERENCES}

1. Bryam, G. M. and Doolittle, W. T. A year of growth for a shortleaf pine. Ecology 31: 27-35. 1950.

2. Daubenmire, R. F. An improved type of precision dendrometer. Ecology 26: 97-98. 1945.

3. Friedrich, J. Uber den Einfluss der Witterung auf den Baumzuwachs. Mitt. a. d. forstl. Versuchw. Osterreichs, 22, Wien. 1897.

4. Halliday, W. E. D. A forest classification for Canada. Can. Dept. Mines and Resources, For. Ser. Bull. 89. 1937.

5. Hartig, T. Uber die Entwicklung des Jahrringes der Holzplanzen. Bot. Ztg. 11: 553-560; 569-579. 1853.

6. Jost, L. Uber Dickenwachstum und Jahresringbildung. Bot. Ztg. 49: 484-495. 1891.

7. Knudson, L. Observations on the inception, season, and duration of cambium development in the American Larch. Torrey Bot. Club. Bull. 40. 1913.

8. Lodewick, J. E. Seasonal activity of the cambium in some northeastern trees. N.Y. State Coll. Forestry, Tech. Pub. 23: 1-52. 1928.

9. MacDougal, D. T. Tree growth. Chronica Botanica, Holland. 1938.

10. Reineke, L. H. A precision dendrometer. J. For. 30: 692-697. 1932.

11. Tryon, H. H. and Finn, R. F. On obtaining precise diameter measurements on hardwoods using the dial gauge. J. For. 47: 396-397. 1949.

12. von Mohl, $\mathrm{H}$. Einige anatomische und physiologische Bemerkungen über das Holz der Baumwurzeln. Bot. Ztg. 29: 225-230. 1862.

13. Warrack, G. and Jorgensen, C. Precision measurements of radial growth and daily radial fluctuations in Douglas fir. For. Chron. 26: 52-66. 1950. 